Entrepreneurship as seen by entrepreneurs in a developing country.

\title{
Authors:
}

Geovanny Mendoza. E-Mail: geovannymendoza26@gmail.com

University of Alicante. Campus San Vicente del Raspeig, San Vicente del Raspeig 03080. Alicante (Spain)

Juan Llopis. Corresponding author. E-mail: juan.1lopis@ua.es

University of Alicante. Campus San Vicente del Raspeig, San Vicente del Raspeig 03080. Alicante (Spain). Phone: 0034965903606

Jose Gasco. E-mail: jl.gasco@ua.es

University of Alicante. Campus San Vicente del Raspeig, San Vicente del Raspeig 03080. Alicante (Spain)

Reyes Gonzalez. E-mail: mr.gonzalez@ua.es

University of Alicante. Campus San Vicente del Raspeig, San Vicente del Raspeig 03080. Alicante (Spain) 


\title{
Entrepreneurship as seen by entrepreneurs in a developing country.
}

\begin{abstract}
Entrepreneurship in developed countries has been the focus of research in countless studies but very few studies have been dedicated to entrepreneurship in developing countries. Within an analysis of entrepreneurship in Latin America, this work focuses on Ecuador and its economic figures, along with the current situation in terms of research on entrepreneurship in the country. It was impossible for us to find nationwide studies about firm creation which have current Ecuadorean entrepreneurs as their direct target population. Hence our decision to collect the opinions of 132 entrepreneurs from all over Ecuador and ask them about the advantages and disadvantages of being an entrepreneur, both qualitatively and quantitatively. Their answers provided us not only with the basis to carry out descriptive statistics, correlation, factor, and cluster identification analyses but also to develop an explanatory model for the potential reduction of unemployment thanks to entrepreneurs' characteristics.
\end{abstract}

Keywords: Entrepreneurship, Business Owners, Survey, Emerging Country, Ecuador 


\section{Entrepreneurship as seen by entrepreneurs in a developing country.}

\section{Introduction}

This work will focus on the reality of entrepreneurship in Ecuador through the opinions of its entrepreneurs. The relevant aspect of this work is that it describes the peculiarities inherent to firm creation in Ecuador. It can be stated at this point that very few, if any, works published in Ecuador have ever referred to this topic, starting directly from the views of entrepreneurs themselves (Ordeñana and Villa, 2014). To achieve our aim, we start by outlining the key aspects of entrepreneurship in general, followed by an examination of the theme from a Latin American perspective. Then we will focus our interest on Ecuador, analyzing its relevant economic and business magnitudes. Finally, attention will be paid to the essential characteristics of Ecuadorean entrepreneurs.

One of the reasons to focus on this country lies in the fact that one of the authors is an Ecuador-born academic and entrepreneur. Our work seeks to fill a gap in the literature by explaining the events that have occurred in the country. This also allows us to provide a much-needed analysis of entrepreneurship in developing countries — something that is rather uncommon compared to those focused on developed countries (Aboal and Veneri, 2016).

In relation to the above, Omri (2020) highlights two reasons for taking an interest in entrepreneurship within the context of developing economies: (A) they show an important orientation towards the market where entrepreneurship plays a very relevant role, and (B) the level of entrepreneurship is much higher than in developed countries due to the existence of fewer barriers to entry and to the strong need to enter because many people cannot find employment alternatives. Hearn and Filatotchev (2019) add that, in developed 
economies, resources for entrepreneurship can be obtained from internal markets. This becomes more complicated in developing countries, which forces them to depend on external markets as well.

Concerning the nature of entrepreneurship, firstly, it must be stressed that, according to Champenois, Lafebvre and Ronteau (2020), entrepreneurship has recently been arousing more and more interest amongst academics. Possible reasons to analyze entrepreneurship are its complexity and that it involves plenty of actions, uncertainties and risks (Meoli et al., 2020). Gupta et al. (2020) point out that from a practical point of view the economic value generated by entrepreneurship is linked to its associated social benefits.

It is important to remember that successful entrepreneurship strongly relates to innovation — mainly of a technological nature (Anderson, Eshima and Hornsby, 2017; Gu, Qian and Lu, 2018; Toms, Wilson and Wright, 2018). It must also be remembered that innovative entrepreneurship may adopt many more formats other than technological (Gumbau, 2017; Mazzei, 2018; Westgren and Wuebker, 2019).

The conclusion reached by Beynon, Jones and Pickernell (2020) that entrepreneurial activity and its consequences constitute an area worthy of research interest if linked to the national environment where it is developed is relevant for this work. More precisely, Cavallo, Ghezzi and Balocco (2019), Chowdhury, Audretsch and Belitski (2019), Farias, et al. (2019), and Fritsch, Sorgner and Wyrwich (2019) point out that the connection between entrepreneurship in a country and its economy constitutes a political issue motivated by an improvement of its citizens' welfare. An even more specific reference can be found in Barba and Atienza (2017), who argue that entrepreneurship acquires a special interest when governments recognize that their actions alone are not enough to generate adequate production and employment standards. 
The expression "entrepreneurial ecosystem" is key as it represents the cultural, social, economic, and political environment that supports the firm creation process (Mazzei, Ketchen and Shook, 2017; Spigel and Harrison, 2017; Dheer and Lenartowicz, 2018). More precisely, Watson et al. (2019), Antonacopoulou and Fuller (2020) and Varlander, Solvell and Klyver (2020) highlight the cultural dimension of entrepreneurship, which leads to some countries being more predisposed to it than others.

Entrepreneurs also need financial, human, and information resources to put their ideas into practice (Baron et al., 2018) and entrepreneurship has long-term consequences (DiazMoriana et al., 2020); hence the importance of researchers studying them. These resources allow entrepreneurs to pursue opportunities related to business growth, innovation, profits or simply to their inability to find a job (Amoros et al.; 2019, Gish et al.; 2019). Although firm creation may be related to the impossibility of finding paid employment, Marshall and Gigliotti (2020) claim that entrepreneurs usually choose this option after having acquired experience working for others. Edwards et al. (2020) even argue that some entrepreneurs create companies knowing that they might earn more money being employed by other people; however, they prefer to become entrepreneurs so that they can set their own ideas in motion. The entrepreneur's degree of commitment is also highlighted by Falele et al. (2020) and Keil, Maula and Syrigos (2017). In short, entrepreneurship can be a long, solitary, and highly stressful journey, but also a joyful, motivating, and satisfying one (Wiklund et al. 2019).

Attention will now be paid to entrepreneurship in Latin America, after which we will deal with the situation in Ecuador. 


\section{Entrepreneurship in Latin America}

The 1980s were a hard period for Latin America in economic terms, to such an extent that they have come to be known as «the lost decade» — an expression utilized by the Economic Commission for Latin America and the Caribbean (United Nations, ECLAC, 2016) to explain the various factors that caused that period of deep crisis. Our paper identifies both internal and external causes which led to high unemployment rates, a slowdown of development in the region, decreases in workers' salaries, an economic drop, higher interest rates, and a reduction of external financial resources —all of which triggered an uncontrolled growth of external debt. While Latin America was immersed in this context, attention started being paid to issues related to entrepreneurship.

The Latin American Administration Organization in its 1983 General Assembly of Representatives approved (through its Porto Alegre Charters or Declarations) the inclusion of the fields of Micro-, Small, and Medium-sized enterprises within its Strategic Development Plan. Since that moment, entrepreneurship has been incorporated into its lines of work for all member nations, as well as in important international events (e.g. the Administration Conferences of Mercosur, of the Andean Community and the Amazon Region, and of Mexico, Central America and the Caribbean.

The development of micro-, small- and medium-sized enterprises currently represents an essential pillar for economic improvement in many Latin American countries, showing that not only large-sized companies can generate employment and contribute to economic growth. This was detected by Espinoza et al. (2019), amongst others, in the case of Chile, by Fischer, Queiroz and Vonortas (2018) and Lasso, Mainardes and Motoki (2019) for Brazil, and by Drinkwater, Lashley and Robinson (2018) for the Caribbean.

Since location is a key decision in entrepreneurship (Adams, Fontana and Malebra, 2017), we agree with Lecuna, Cohen and Chavez (2017) that entrepreneurship in Latin 
America strongly relates to export activity, since the domestic market is not powerful enough to absorb the generated supply.

For instance, according to an Ecuador Central Bank report (2019), despite the economic growth experienced in Latin America, entrepreneurship businesses evolve and grow slowly compared to those located in other regions. $70 \%$ of the population work in small enterprises that have fewer than five employees. Even though these figures would normally imply a considerable economic growth, that is actually not the case, insofar as these firms are usually born small and tend to stay small.

Following the criteria applied by Lederman et al. (2014), there are many possible reasons why Latin American enterprises grow slowly, lack of innovation standing out as one of the most significant. In their opinion, such enterprises need to innovate on a permanent basis in order to grow (or even to survive). They thus recognize that new products enter less frequently than in other economies, and also that entrepreneurs' management is usually far away from the best practices implemented worldwide. Furthermore, patent registration lies well below the reference levels. Several of the firms located in this region carry out some kind of innovation, albeit often with low effectiveness or with insufficient results to succeed in stimulating productivity or to be replicated in contexts with similar characteristics. Iliescu (2014) also mentioned the effects of globalization in this respect.

It is also worth mentioning — following Guimon and Paraskevopoulou (2017) — that a large part of entrepreneurship in Latin America has its origins outside this region. Puente, Gonzalez and Cervilla (2019) added that Latin American countries share a high entrepreneurship rate based on a necessity-related motivation. However, this does not result in increased economic growth, as could have been expected a priori. 
Overall economic growth for Latin America in 2018 stood at 3.3\%. Nevertheless, lower growth rates are expected for 2020 because of the increased uncertainty around future growth dynamics. By way of example, the global economy showed a high degree of growth synchrony in 2017; economic improvement took place in both developed and developing economies. This acceleration of growth within a low-inflation and highliquidity environment resulted in low volatility in the financial markets.

This panorama began to change in 2019, though. The expansion occurring during this year essentially reflects the growth of the United States (2.8\%), supported by the fiscal stimulus, which should reveal signs of exhaustion in 2019 — and of China (6.6\%), which also foresees lower growth rates for 2019. The Eurozone has been gradually revising its growth forecasts downward to $2.2 \%$ - as opposed to $2.4 \%$ in 2017 . In the United Kingdom, the increased interest rates added to the process of negotiation to leave the European Union (Brexit) took the growth rate down to 1.5\% in 2018 (compared to $1.8 \%$ in 2017). As for Japan, its productive capacity has recently shown certain restrictions that would explain the slower pace of expansion in 2018: a growth rate in the region of $1.1 \%$, $0.6 \%$ below the previous year.

This lower synchrony in the acceleration dynamics further worsens by the risks of commercial conflicts. President Trump's government has adopted several tariff increases since 2018. Some of them were specifically targeted at China, followed by the European Union, while others have a broader scope.

Faced with this global context, for 2019 the current account deficit of Latin American and Caribbean countries rose to $1.6 \%$ of the regional Gross Domestic Product (GDP). Both the balance of goods and that of current transfers are likely to maintain surpluses, but this would be offset by a higher deficit in the income and service account. A $9 \%$ growth in the value of Latin American exports is expected for 2019 as a result of the 
higher prices achieved by exportable goods. The exported volume increase will probably be moderate, though (ca. 2\%). In turn, the slight recovery of domestic demand together with higher oil prices may help maintain the import value growth at just above $9.5 \%$, with a $4.1 \%$ price rise.

\section{Ecuador's macroeconomic context}

Our attention will now focus on the Ecuadorean macroeconomic context, seeking to deal with the general aspects and the long-term objectives. This allows us not only to analyze the economic situation but also to understand the phenomena involved in it through the analysis of specific variables that will be briefly described below using data provided by INEC [(Ecuadorean) National Institute of Statistics and Censuses] (2019).

With a surface area of $256,370 \mathrm{~km}^{2}$ and a population of $17,120,000$ inhabitants (its population density amounting to 66 persons per $\mathrm{km}^{2}$ ), Ecuador occupies the $68^{\text {th }}$ position in the world. The unemployment rate lies at $4.4 \%$ (rising to $5.7 \%$ in urban areas) and the US dollar is Ecuador's official currency. The country has a per capita GDP of 5,392 euros (92 ${ }^{\text {nd }}$ position globally) and its HDI (Human Development Index) - a United Nations instrument used to measure the standard of living — places Ecuador in the world's $87^{\text {th }}$ position.

According to the latest data published by the Central Bank of Ecuador (2020), GDP in 2019 was 107,425 million US dollars, per capita income amounting to 6,221 dollars - it was 6,318 in 2018 - with a population that grew from 17,023,408 in 2018 to $17,267,986$ in 2019.

The most recent data published by Ecuador's National Statistics Institute (INEC, 2020) reveal that almost 900,000 enterprises registered in this country in 2018 , with just 
above $3,000,000$ jobs (60\% male and $40 \%$ female), showing a proportion of 528 companies for every 10,000 inhabitants.

Furthermore, the World Bank (2019a) annually publishes the "Doing Business" index, which measures how easy it is to do business in a country by assessing the following dimensions: opening of a business, management of building permits, availability of electricity, registration of properties, availability of credit, protection of investors, payment of taxes, cross-border trade, contract fulfillment, and insolvency resolution. In accordance with this ranking, Ecuador stands in the $123^{\text {rd }}$ position amongst the 190 evaluated countries.

As far as the Competitiveness Index is concerned, Ecuador ranks $90^{\text {th }}$ on a list of 141 analyzed countries. This index published by the World Economic Forum measures the use of resources and capabilities by a country translated into its inhabitants' prosperity level (Global Competitiveness Report, 2019).

Ecuador could be more specifically described as a country with a small economy that essentially depends on oil exports, even though it is recognized as the world's most important banana exporter and as one of the main exporters of flowers, shrimps and cocoa —in addition to primary commodities. The external debt in the country dates back to the late 1970s, although its higher indebtedness levels originated in the subsequent decades (CAIC, 2007). These incidents were followed by the structural changes experienced during 1999, the year when Ecuador went through its worst economic and financial crisis due to the freezing of bank deposits — which absorbed $50 \%$ of the current incomesadded to the inability to pay, the moratorium of the Brady bonds and the Eurobonds (equivalent to $118 \%$ of the GDP). It all resulted in a debt of 13.564 billion dollars in 2000 , within a dollarized environment, accompanied by massive unemployment rates, increased prices of goods and services, suspension of wages and salaries in the educational sector 
as well as in healthcare, the police and the military, along with a reduction of investments and a growing distrust of the country (Larrea, 2007).

The dollarization of the economy has played an important role in the endogenous crisis of the Money Supply suffered by the Monetary and Financial Sector. This is further complicated by the political situation with the succession of seven presidents between 1995 and 2006, which highlights the difficulties that the country is currently undergoing. For Olmedo (2016), this crisis is mainly related to the low levels of income in the assets and goods market that affect both the Balance of Payments and the Domestic Demand for money. In this connection, Ecuador's Central Bank published the following statement in an Official Communiqué in 2015:

"The truth is that dollarization can only be defended with better results in the balance of payments and higher efficiency in domestic liquidity management. Accounting schemes and formal rules cannot achieve the same degree of success as economic results." (Ecuadorian Central Bank, 2015, cited in Olmedo, 2016).

According to Serrano and Vera (2016), this whole context contributed to the triggering of the financial and social crisis of those and the following years, during which external indebtedness and economic growth have experienced nationwide macroeconomic distortions. The large protests witnessed in October 2019 derived from this period.

In relation to the manufacturing sector, it is worth highlighting that Ecuadorean industry reveals a strong predominance of craft activity, more specifically in the production of footwear and clothing, metal-mechanical products, furniture, timber, and food. This industry accounted for 11.9\% of the national GDP between 2006 and 2013. According to INEC (2019), 64,258 manufacturing firms —a large proportion of which belong to the micro-enterprise segment (89\%) — are based in Ecuador at present, followed 
by small-size enterprises with $8 \%$, medium-sized firms with $2 \%$, and large-sized ones with $1 \%$. Food, textiles, chemicals, and mechanical products are the most heavily represented sectors.

The agricultural sector shows serious socioeconomic problems related to the migration of young people towards cities and abroad as a result of their demotivation due to the low agricultural income. In parallel, the Agrarian Act Legislation is perceived as a threat by the families whose fields are not productive, since it grants the Government the right to expropriate those fields with the aim of turning them into productive ones. This ultimately implies that the owning family runs the risk of losing a part of their property (Cho Tana, 2015).

The performance of the Ecuadorean economy over the last ten years has deepened the State's involvement both in investment and in expense generation. Although Ecuador invested its oil revenues, it did not redound to job creation from entrepreneurship actions.

Focusing on economic activities and spatial location, the ICEX report [Network of Economic and Commercial Offices of Spain Abroad] (2019) shows that economic activity revolves around few locations, especially the cities of Quito and Guayaquil. The former houses the central government - with the economic impact that this entails, especially for the service sector. Also, the country's most important companies are based there i.e., public enterprises, large foreign firms, and most of the larger-sized Ecuadorean companies. Commercial activity in Guayaquil revolves around its seaport, which exports locally produced bananas, cocoa, and shrimp. Apart from the two biggest cities, the regional and even locally produced specialties deserve a mention. Thus, Cuenca - the country's third most populated town - is a center for craft-related businesses and the ceramic industry; and Manta is considered the world capital of tuna. Esmeraldas (in the north-east) has oil refineries as its main activity, and the Amazon region (in the east) is 
the most important location for hydrocarbon exploitations (even though the companies belonging to this sector are based in Quito). The Galapagos Islands focus on tourism. Such a high degree of specialization, which is visible even in smaller municipalities, transforms the country into a long list of small economic activity centers.

According to the World Bank, the formalities required to set up an enterprise in Ecuador went down from 92 days in 2003 to 49 days in 2018. This highly positive record - a considerable improvement indeed - is still insufficient, since less than a week is needed to complete such formalities in many OECD countries (World Bank, 2019b).

Some specific real limitations exist which slow down the growth and development of small and medium-sized enterprises in Ecuador (Proaño, 2015). There are inadequacies in the training required to conceive a coherent creation of firms in line with innovation and adaptation to change. From this author's point of view, many of the limitations in terms of training might be alleviated if primary, secondary, and university education concentrated on developing certain skills and capabilities. This would help identify opportunities, analyze resources, assess ideas through which entrepreneurial projects can be implemented and eventually materialize into new businesses. Along the same lines, one could speak about innovating or reinventing such businesses depending on the different circumstances.

Ponguillo and Mayorga (2016) insisted on the previously mentioned negative aspects, additionally suggesting that other reasons such as the discontinuity of the Government's policies addressed to entrepreneurs should be taken into consideration. According to these scholars, the limited financial support, the lack of credit, risk capital and investor networks, along with the absence of stock market products, stand out as the key weaknesses associated with entrepreneurship. They also stress that the promotion of education at all levels must be seen as a critical axis in state policies. 
The same line of reasoning was shared by Zamora (2017). This author pointed out that, although public participation has covered a wide spectrum —including a legal and institutional framework as well as schemes to provide resources and advice- its continuity was not as good as expected, which influences the effectiveness of the policy in question. Added to this, the Ecuadorean government has failed to monitor the results obtained through the implementation of these initiatives, which would have allowed it to assess their effectiveness with a view to strengthening or taking new courses of action and ultimately to avoiding resource use inefficiency.

\section{Characteristics of Ecuadorean entrepreneurs}

In this section, we will describe the situation in terms of works about entrepreneurship in Ecuador. The emphasis centers on contextualizing and grouping together the distinctive and most relevant features of Ecuador's entrepreneurs based on the most important research studies undertaken in this regard.

It must firstly be said that no significant differences seem to exist between the average Latin American entrepreneur and an Ecuadorean one, above all in their differentiation by economic income, as well as in terms of their personality. Some disparities need to be underlined, though, amongst them the higher salaries and the improved exploitation of businesses as an innovative component, along with the approach to minor management problems - including access to clients, suppliers, funders, and skilled labor (Gluzmann, Jaume and Gasparini, 2012; Development Bank of Latin America, 2015).

Villarroel et al. (2005) provided an overall identification of the average Ecuadorean entrepreneur as confident, organized, informal, competitive, and risk-averse. They seek 
stability, have experience in the activity, and use self-realization, the contribution to society and the practical implementation of their knowledge as sources of motivation.

The analysis of these general characteristics is germane to the profile of an Ecuadorean entrepreneur presented by Araque (2012), characterized as someone with formal studies who prefers to acquire working experience over the years and whose entrepreneurial development was not based on a business plan, and who maintains young enterprises, usually created by a need and a desire for independence.

In turn, Merizalde (2017) identified the behavior of Ecuadorean entrepreneurs inside a family business, mostly generated out of necessity and facing difficulties during its creation process. This business type, which focuses on the local market, revolves around retail and services. Its primary source of financing lies in own resources, which simultaneously represents a limitation due to the need to utilize old technologies, at least in the early years of operating.

The use of aggregate data and database analysis allowed Maldonado, Lara and Maya (2018) to draw a more explicit conclusion: a growing predisposition to set up new business exists in Ecuador and, although a changed trend towards opportunity-based motivation has become visible in recent years, necessity-based motivation still prevails.

Valencia and Gualdrón (2016) considered that the most recurrent problems in this type of business have to do with lack of resources, a perception of insufficient support, internal business administrative problems, an inadequate legislation, and finally, an insufficient volume of scientific and technological research in the interest of the business itself. Lara and Maldonado (2015) added that Ecuadorean entrepreneurs desist at an initial stage due to several relevant factors. Amongst them stand out the absence of financial incentives, a lack of continuity in the actions derived from the implemented public policies, the 
presence of stronger competitors, the absence of innovation or simply the fact that they found new work opportunities.

Regarding the influence of the business environment, Rovayo (2010) argued that it exerts a key influence on the attitudes, activities, and aspirations of entrepreneurs in Ecuador. This author referred to the contribution which should be made by three main actors - the State, private enterprise, and academia - when it comes to ensuring the development of a favorable climate for entrepreneurship. Each one plays a key role and must assume their own challenges. Rovayo additionally highlighted that the impact level of entrepreneurship in Ecuador represents a huge challenge, since excellent ideas and initiatives often arise, some of them are eventually implemented, but only a few entrepreneurs succeed in maintaining them over time.

On another note, according to GEM [Global Entrepreneurship Monitor] (2018), Ecuadorean society mostly welcomes the incorporation of entrepreneurship. This report stresses the fact that perceptions around opportunities and the chances of being able to set up a business are significantly positive in Ecuador — and well above the regional average.

Nevertheless, this report also refers to the urgent need for legislation that can provide an agile legal framework for entrepreneurial activity. It is likewise suggested that specific financial products for entrepreneurs should be developed and that entrepreneurial education should form part not only of secondary and university education but also of primary education. The opening of Ecuador's market through international agreements as well as an improved transfer of research to companies are paths that need to be explored in much greater depth too.

Arbito and Andrea (2015) specified a series of personal attributes associated with food sector entrepreneurs in the Ecuadorean city of Guayaquil. Following an analysis of 
several bibliographical references, the following peculiarities stood out: people who like to run their own company, committed to succeed with the aim of accomplishing their aims and goals, not too risk-averse, and with a positive predisposition to accept criticism or suggestions which can enable them to carry out improvements and to grow in the market. They additionally expressed their willingness to invest in their own human capital.

In turn, López et al. (2017) provided some data about entrepreneurship drawn from Ecuadorean university graduates:

- Around $37 \%$ of entrepreneurs are 25 to 35 years old.

- Their main motivation is the lack of employment; hence, why many new enterprises place the emphasis on generating self-employment.

- Access to sources of financing is limited.

Considering their ages, it becomes clear that this population belongs to the segment of the so-called 'millennials' (the twenty-first-century generation). It is worth highlighting for its relevance to the future of Ecuador's entrepreneurs that they all share the characteristic of having been born in the period during which the technological revolution produced its most important outcome: massive and domestic access to data through the Internet (Ferrer, 2010). A second characteristic common to them all is their status as young people with interests who wish to move up the job ladder quickly. They aspire to occupy leadership positions and own the skills to adapt to new conditions while simultaneously solving problems (Universum, 2014).

In tune with the views expressed by Solines and Antonieta (2016), and within their research findings, they described young millennials as being creative and active, and showing a positive predisposition towards mistakes. They see practice as an essential methodology and are convinced that you can not only learn from mistakes but also 
improve through them. Furthermore, millennials permanently stay in contact with one another, using the Internet as a key learning tool.

After analyzing the fundamental features of entrepreneurship in Latin America, offering the economic figures corresponding to Ecuador, and describing the research on entrepreneurship in Ecuador, the focus will now be placed on our own research study.

Prior to that, it needs to be said that the works available for us to study were based on secondary data and general statistics, the orientations of entrepreneurship identified amongst university students, the examination of business set-up actions in a specific town, and the analysis of a particular economic sector. It was impossible to find research works of a national scope about the creation of enterprises in Ecuador which have Ecuadorean entrepreneurs currently developing their business activity as their target population.

Even though the studies mentioned above are undoubtedly of great interest, a need exists in our opinion for a type of research undertaken from the specific perspective of entrepreneurs whose business is operational at present. This will allow us to compare the difficulties faced when they set up their firms and the ones that they are experiencing now. To this end, a nationwide Ecuadorean sample is offered with a representation of the different firm sizes, sectors, and degrees of business development according to the enterprise's life cycle.

Entrepreneurs were asked about their technical knowledge, creativity, perseverance, tolerance of failure, and interpersonal skills. Our interest also focused on learning about their emotional states related to uncertainty, failure, fear, anxiety, and despair.

Likewise, this research sought to know entrepreneurs' views about innovation, the business idea, capital (goods, money, machinery...), the organization (the managerial team that will shape the entrepreneurial initiative), human talent, the entrepreneurial ecosystem (relationships between the entrepreneurial entities and individuals and their 
technological, academic, social, political, and economic environments), financing, support programs, and the experience of entrepreneur teachers.

Another of the key issues worth enquiring about was the most important impediments found when trying to undertake an enterprise. Some examples are: lack of subsidies, absence of financing, too many taxes, excessive formalities, poor training in the field, unavailability of up-to-date technology, and absence of emotional backing from relatives and friends.

\section{Methodology}

The main criteria to establish the sample used in this study were representativeness, relevance, and access to entrepreneurs. Our sample comprised 132 firms belonging to different Ecuadorean regions which, according to the number of workers, can be classified as large-sized (over 250 workers), medium-sized (up to 250 workers) and smallsized enterprises. The latter can in turn be subdivided into small (under 20 workers) and micro-enterprises (below 10 employees). Table 1 lists the technical specifications of our study.

\section{TABLE 1 HERE}

These instruments were applied on a self-administered basis, providing them directly to participants or via electronic mail depending on the distance involved in each case (after a telephone contact to explain the aim of our study). A survey was designed with multiple-choice questions that had been previously defined and elaborated from a series of statements on the study object. The conception and structuring of this questionnaire adopted a 7-level Likert-type scale format with the aim of reflecting the assessment criteria. 
Three criteria were followed to select the enterprises: activity sector, average size in terms of annual sales and staff volume, and geographical area representative of the whole national Ecuadorean territory. The survey questionnaire was answered by the company founder or, failing that, by the current CEO. In Ecuador, the e-mail addresses of these CEOs can be easily accessed in the databases available.

The survey questionnaire designed for entrepreneurs brought together the information, organizing it around three sections: interviewee's profile, considerations on entrepreneurship, and assessments of entrepreneurship support schemes.

Five experts were consulted to validate the survey questionnaire during its design process, namely: an academic from Ecotec University, a professional advisor on entrepreneurship from the Financial Corporation: League of Entrepreneurs, and 3 businessmen belonging to the following public limited companies: Plásticos Tropicales Plastro, Envases del Litoral, and Litomovil.

In addition to carrying out a separate evaluation of each question, they assessed the pertinence and adequacy of the questionnaire as a whole. The survey was subsequently deemed as validated in terms of the specific questions chosen, the order in which they appeared, and the possibility of adding unasked questions, all of it bearing in mind Ecuador's business reality and entrepreneurship levels.

It must be highlighted at this stage that the draft presented to experts for validation was accepted with only a few minor changes being proposed. After a second consultation round, all the experts agreed that the questions and statements clearly expressed the information requested from the interviewees.

It thus seemed to us that the understanding was good enough to answer the questionnaire. This allowed us to accurately identify the level of agreement amongst 
respondents, the degree of importance assigned to a specific factor, and the chances of undertaking future actions through the indicators used to assess entrepreneurship in Ecuador.

\section{Results and discussion}

Firstly, the Cronbach's alpha coefficient value of 0.718 for the questionnaire items means that its consistency level is high.

As for the profiles of the 132 interviewees, $62.2 \%$ were males and $37.8 \%$ females. In terms of age, $49.9 \%$ are between 18 and 30 years of age, $34.3 \%$ being 31 to 50 years old. The remaining $15.8 \%$ are older than 50 .

Concerning Ecuadorean economic sectors linked to entrepreneurship, the following ones stand out (in descending order): Commercial (sale and purchase of goods and services) (37\%), Gastronomy (11.8\%), Tourism (14.3\%), and professional activities (7.6\%). Other sectors with a lesser degree of participation can be mentioned as well: Social Services (6.7\%), Transport (5.0\%), Technology (5.9\%), Esthetics (4.2\%), and Education (3.4\%). Finally, some sectors not mentioned above account for $4.1 \%$.

A majority of respondents (55.5\%) explained that the characteristics of their business matched those of a micro-enterprise. $29.4 \%$ of them described their business as a smallsized enterprise, while another $14.3 \%$ thought that theirs was a medium-sized enterprise, and only $0.8 \%$ classified their business within the profile of a large-sized firm.

As far as business location is concerned, Table 2 clearly shows the representativeness of a sample that covers the whole territory of Ecuador.

TABLE 2 HERE 
Special attention must be paid to the question about the origin of the enterprise's capital (Table 3), where the importance of foreign private capital in business creation becomes visible.

\section{TABLE 3 HERE}

In response to the question in which interviewees were asked about their stage of evolution as entrepreneurs with four options, $87.3 \%$ claimed to find themselves in the 3 early entrepreneurship stages. More precisely, $34.3 \%$ of them chose the idea gestation stage, $33.3 \%$ the setting in motion stage, and $19.7 \%$ the initial development stage. Only $12.7 \%$ of our respondents placed themselves in the growth and consolidation stage. These findings confirm that the Ecuadorean population is highly interested in undertaking entrepreneurial activities, since they find themselves in incipient stages of the process. This last aspect does not significantly differ from the insights provided by Puente, Gonzalez and Cervilla (2019) about Latin America as a whole.

Below can be found the results obtained in relation to entrepreneurs' views and their links with the likelihood of reducing the unemployment rate in Ecuador. One of the questions referred to the level of specific technical knowledge, creativity, perseverance, tolerance of failure, and interpersonal skills that the interviewees believed themselves to have (on a 1-to-7 Likert-type scale, where 1 means "I totally disagree" and 7 "I totally agree"). These were the average values obtained:

- Specific technical knowledge (5.11)

- Creativity (5.53)

- Perseverance (5.72)

- Tolerance of failure (5.03)

- Interpersonal skills (5.72) 
Even though both Gu, Quian and Lu (2018) and Varlander, Solvell and Klyver (2020) mention perseverance, the appearance of interpersonal skills as the most highly valued option is more closely associated with Ecuadorean entrepreneurs as one of their own features.

A variance analysis (ANOVA) test was applied to the results obtained in this question. With a $95 \%$ confidence interval, a statistically significant difference exists between the different groups ( $\mathrm{p}$-value $<0.05)$. There are indeed statistically significant differences between the decrease of unemployment and a high level of technical knowledge, creativity, perseverance, tolerance of failure, and interpersonal skills. The equality of means null hypothesis is consequently rejected. This suggests that an improvement of such indicators will most probably have a positive influence on the reduction of the Ecuadorean unemployment rate.

The next questionnaire item asked respondents about their ability to handle the emotional states associated with uncertainty, failure, fear, anxiety, and despair (on a 1-to7 Likert-type scale, where 1 means "I totally disagree" and 7 "I totally agree"). Below can be found the mean values obtained:

- Uncertainty (5.29)

- Failure (5.03)

- $\quad$ Fear (5.25)

- Anxiety (5.34)

- Despair (5.39) 
Uncertainty and anxiety are also identified by Marshall and Giglitti (2020), who argue that some correspondence exists between having had a previous job and undertaking business in the same sector. Nevertheless, despair - the characteristic most often mentioned here- does not usually appear in the literature.

After performing the ANOVA test, a statistically significant difference was found between the different groups ( $p$-value $<0.05$ ) with a $95 \%$ confidence interval. This means that the equality of means null hypothesis is rejected. In other words, evidence was obtained about the existence of statistically significant differences between the decrease of unemployment and the management of emotions. A positive predisposition towards the management of emotional states improves the conditions to undertake business activities, which could in turn help reduce unemployment rates.

Another question was about the importance assigned to certain aspects when it came to undertaking entrepreneurial activities (on a 1-to-7 Likert-type scale, where 1 means "I totally disagree" and 7 "I totally agree"). These aspects included: innovation, the business idea, capital (goods, money, machinery...), the organization (the managerial team that will shape the entrepreneurial initiative), human talent, the entrepreneurial ecosystem (relationships between the entrepreneurial entities and individuals and their technological, academic, social, political and economic environments), financing, support programs, and the experience of entrepreneurship teachers.

These are the average values achieved:

- Innovation (5.98)

- Business idea (6.03)

- Capital (6.13)

- The organization (5.51) 
- Human talent (5.82)

- Entrepreneurial ecosystem (6.23)

- Financing (6.36)

- Support schemes (5.91)

- Experience of entrepreneurship teachers (4.50)

Comparing these results with the literature shows that innovation ranks fourth as a key entrepreneurship aspect —when authors such as $\mathrm{Gu}$, Quian and $\mathrm{Lu}, 2018$ ) and Toms, Watson and Wright (2018) had considered it a first-order factor. It becomes clear once again that financing is essential for Ecuadorean entrepreneurs. Nonetheless, the entrepreneurial ecosystem — which appears in second place in our study - is indeed widely recognized, as attested by Spigel and Harrison (2017) and Watson et al. (2019).

The ANOVA analysis reveals the existence of statistically significant differences (pvalue $<0.05)$ - with a $95 \%$ confidence interval — between unemployment reduction and the entrepreneurship reality. The highest importance corresponds to innovation, the business idea, capital, the organization, human talent, the entrepreneurial ecosystem, financing, the support schemes, and the experience of entrepreneurship teachers. In other words, the equality of means null hypothesis is rejected. Therefore, strengthening these factors will most probably have a positive impact on decreasing the unemployment rate in Ecuador.

As for the greatest impediments which affect them when trying to undertake business activities, our interviewees were asked about the following: lack of subsidies, absence of financing, too many taxes, excessive formalities, poor training in the field, unavailability 
of up-to-date technology, and absence of emotional backing from relatives and friends (on a 1-to-7 Likert-type scale, where 1 means "I totally disagree" and 7 "I totally agree").

The descriptive statistics provided the following average values:

- $\quad$ Lack of subsidies (5.34)

- Absence of financing (5.74)

- Too many taxes (5.54)

- Excessive formalities (5.48)

- Poor training in the field (5.69)

- Unavailability of up-to-date technology (5.55)

- Absence of emotional backing from relatives and friends (3.57)

As seen above, the most outstanding source of reluctance is "absence of financing", followed by "training in the field". Financing needs appear in the literature as an obstacle for firm creation — by way of example, see Baron et al. (2018). Lack of training is less often shared in the literature — an example can be found in Gish et al. (2019).

According to the ANOVA analysis, statistically significant differences exist ( $p$-value $<0.05)$ - with a $95 \%$ confidence interval — between the reduction of unemployment in Ecuador and the most important obstacles to set up businesses. The equality of means null hypothesis is consequently rejected. It follows from these findings that working on these impediments might help lower the Ecuadorean unemployment rate.

Based on the above, something else deserves to be pointed out in an aggregated way with regard to all our research items about the outcomes of entrepreneurship alongside its consequences and effects on the reduction of unemployment in Ecuador. The variable 
"unemployment decrease" depends on the following factors with their respective means (the minimum value being 1 , and the maximum one 7):

- State Support (SS): 5.58

- Financial Support (FS): 3.83

- Training in the Field (TF): 5.89

- Technical Knowledge (TK): 5.42

- Emotional State (ES): 5.27

- Multidimensional approach of the programs to be developed (MA): 5.97

- Entrepreneurship promotion (EP): 4.24

As for the strengths of entrepreneurship, Ecuadorean entrepreneurs stand out for adopting a transversal approach to firm creation. This strength fits in with the arguments suggested by Omri (2020) to succeed in entrepreneurship. Practical training is scored next, followed by state support in third place.

Relating state support to the cultural and political side of entrepreneurship, this finding is in tune with what seems desirable according to most of the literature (e.g. Mazzei, Ketchen and Shook, 2017; Spigel and Harrison, 2017; Chowdhury, Audretsch and Belitski, 2019; Farias et al., 2019).

Table 4 brings together the most outstanding results in each section to highlight the aspects that most determine Ecuadorean entrepreneurs' motivations and objections. The answers with the highest scores in each section of the questionnaire is shown to that end.

TABLE 4 HERE 
Table 5 offers a correlations matrix for the preceding variables. It can be seen (last row or last column) that these variables are related on a linear basis. Or expressed differently, that unemployment linearly and positively correlates with the variables. This can be interpreted in the following way: as SS, FS, TF, TK, ES, MA, and EP increase, so does Unemployment Decrease (UD). The fact that a correlation exists does not imply that there is causality; hence why a linear regression will be carried out next in order to explain the possible relationships between variables.

\section{TABLE 5 HERE}

The model for the linear relationship would read like this:

$$
\mathrm{UD}=?_{0}+?_{1} \mathrm{TK}+?_{2} \mathrm{ES}+?_{3} \mathrm{FS}+?_{4} \mathrm{EP}+?_{5} \mathrm{SS}+?_{6} \mathrm{TF}+?_{7} \mathrm{MA}
$$

The application of this model leads to the results shown in Table 6.

TABLE 6 HERE

The value of 0.755 for R tells us that —at $75.5 \%$ - the variables TK, ES, FS, EP, TF, and MA are linearly related to the variable 'Unemployment Decrease.'

Table 7 below shows the ANOVA analysis, after which Table 8 provides the model coefficients.

TABLE 7 HERE

TABLE 8 HERE

This is consequently how the model comes to be expressed:

$$
\begin{aligned}
\mathrm{UD}=-0.799 & +0.248 \mathrm{TK}-0.029 \mathrm{ES}+0.032 \mathrm{FS}+0.142 \mathrm{EP}+0.033 \mathrm{SS} \\
& +0.223 \mathrm{TF}+0.585 \mathrm{MA}
\end{aligned}
$$


This model demonstrates that interviewees' opinion about a multidimensional approach program plays an important role in the effort to reduce Ecuador's unemployment rate. Another two criteria to be borne in mind according to the conception of our respondents are: entrepreneurs' technical knowledge, and training in the field.

From the previous analysis, a cluster analysis was performed after calculating the Kaiser-Meyer-Olkin sampling adequacy measure, Bartlett's sphericity test, and the rotated component matrix (using an extraction method through a principal components analysis and a Varimax normalized rotation method with Kaiser). In short, three clusters can be grouped together, associated with unemployment reduction and shaped by the following groups of variables:

Cluster 1: Security, represented by the answers to questions about financial support and entrepreneurship promotion (FS and EP).

Cluster 2: Interviewee's profile; this cluster joins technical knowledge with the respondent's emotional state (TK and ES).

Cluster 3: Support Received, represented by the variables which explain state support, training in the field, and the multidisciplinary approach model (SS, TF, and MA).

\section{Conclusions}

As argued in this work, Ecuador can be categorized as a developing country located in Latin America which has its own specific features regarding entrepreneurship.

It was impossible for us to find research works of a national scope about the creation of enterprises in Ecuador which have Ecuadorean entrepreneurs currently developing their business activity as their target population. In our view, the need existed for a 
research study from the specific perspective of entrepreneurs whose business is operational. This permits an empirical comparison between the problems and advantages faced when they set up their firm and those experienced at present.

The examination of the most frequent answers offered by Ecuadorean entrepreneurs allows us to design the characteristics of a standard entrepreneur in this country with an emergent economy: a man between 18 and 30 years of age, business dedicated to the sale and purchase of goods and services, micro-enterprise, located in a big city, financed with foreign capital, at the stage of introduction in the market within the enterprise's life cycle, he has interpersonal skills, he does not despair when things are not going well, and he assigns great importance to financing. The latter is in tune with the cluster labelled as "security" — where most entrepreneurs place themselves. The dimensions of financial support and entrepreneurship promotion also seem to be especially appreciated.

Delving deeper into the most relevant aspects of this study about Ecuadorean entrepreneurs, some conclusions can be drawn concerning its key outcomes. It can thus be stated that the most highly recognized features owned by these entrepreneurs are personal and managerial skills. Despair control stands out when it comes to managing their emotions.

Financing is once again stressed as a fundamental aspect of entrepreneurship. Being innovative, finding oneself in a suitable entrepreneurial ecosystem, and having a good business idea trail behind financing. This actually contradicts the literature on entrepreneurship (Gumbau, 2017; Anderson, Eshima and Hornsby, 2018; Mazzei, 2018; Toms, Wilson and Wright, 2019) and, in our view, should be changed when it comes to managing entrepreneurship and providing training for it in Ecuador. 
Regarding sources of reluctance, it deserves to be highlighted that the response about lack of financing receives a higher score than those referring to lack of training, unavailability of adequate technology, and bureaucratic impediments. As for entrepreneurship strengths, a special mention must be made of having a transversal to firm creation — which does provide a multidisciplinary vision of interviewees.

On the whole, it can be concluded that Ecuadorean entrepreneurs differ from those undertaking business elsewhere in Latin America, as well as in other geographical areas, in the essential importance attributed to the financing of their projects. For Ecuadorean entrepreneurs, financing comparatively outweighs the other factors that may positively or negatively influence the success of their initiatives. Despite this being a reality intrinsic to the entrepreneurship phenomenon, it becomes even more pressing in the case at hand.

A potential practical implication might be the opportunity of the financial market, insofar as this strengthens the demand for capital to create companies. Alongside the above, training and institutional support programs should further emphasize the key importance of aspects such as innovation, suitable technology or business plan development. Being aware of these fundamental factors as well as developing them acquires great relevance, not only for firm success but also to achieve financing. In effect, regardless of the modality, investors pay attention to such issues when the time comes to inject funds for projects (Gu, Quian and $\mathrm{Lu}, 2018$; Westgren and Wuebker, 2019). Entrepreneurs' willingness to adequately deal with innovation, cutting-edge technology or business plans may indirectly open doors for them to receive financing.

As for future works, it seems relevant to undertake similar analyses in neighboring countries located within this particular environment, and in emergent countries in general, with the aim of comparing the idiosyncrasies of business set-up actions in Latin America as a whole, and more specifically, of drawing a comparison between emergent and 
consolidated countries. A longitudinal analysis would also be desirable to examine the evolution of Ecuadorean entrepreneurs over time.

With regard to the limitations faced in this research study, it must be highlighted that, despite having collected the opinion of entrepreneurs with a geographically significant sample and by activity sectors, the number of valid survey questionnaires should increase in subsequent research works, so that conclusions can become more robust. Another limitation lies in the fact that we have worked with the opinion of only one person per firm, even if it is the founder of the CEO. Collecting the opinion of other organization members might enrich the study, while simultaneously improving result validity.

\section{Bibliography}

Aboal, D. \& Veneri, F. (2016). Entrepreneurs in Latin America. Small Business Economics. 46(3), 503-525.

Adams, P., Fontana, R. \& Malebra, F. (2017). Bridging knowledge resources: the location choices of spinouts. Strategic Entrepreneurship Journal. 11(2), 93-121.

Amoros, J.E., Ciravegna, L., Mandakovic, V. \& Stenholm, P. (2019). Necessity or opportunity? The effect of state fragility and economic development on entrepreneurial efforts. Entrepreneurship Theory and Practice. 43(4), 725-750.

Anderson, B.S., Eshima, Y. \& Hornsby, J.S. (2018). Strategic entrepreneurial behaviors: Construct and scale development. Strategic Entrepreneurship Journal. 13(2), 199-220.

Antonacopoulou, E. \& Fuller, T. (2020). Practising entrepreneuring as emplacement: the impact of sensation and anticipation in entrepreneurial action. Entrepreneurship \& Regional Development. 32(3-4), 257-280.

Arbito, P. \& Andrea, M. (2015). Atributos personales y del negocio de los emprendedores del sector de alimentos, que constituyeron sus emprendimientos en la ciudad de Guayaquil (PhD thesis, Universidad Casa Grande. Facultad de Administración y Ciencias Políticas).

Araque, W. (2015). Emprendimiento en Ecuador. Ekosnegocios.com, 9(4), 51.

Banco Central de Ecuador (2019). Statistics reports. https://www.bce.fin.ec/index.php/informacioneconomica. Accessed 14 October 2019. 
Banco Central de Ecuador (2020). GDP Ecuador.

https://sintesis.bce.fin.ec/BOE/OpenDocument/1602171408. Accessed 10 July 2020 .

Barba, V. \& Atienza, C. (2017). Entrepreneurial motivation and self-employment: evidence from the expectancy theory. International Entrepreneurship and Management Journal. 13(4), 1097-1115.

Baron, R.A., Tang, J., Tang, Z. \& Shang, Y. (2018). Bribes as entrepreneurial actions: Why underdog entrepreneurs feel compelled to use them. Journal of Business Venturing. 33(6), 679-690.

Beynon, M.J., Jones, P. \& Pickernell, D. (2020). Country-level entrepreneurial attitudes and activity through the years: A panel data analysis using fsQCA. Journal of Business Research. 115, 443-455.

CAIC. (2007). Comisión para la Auditoría Integral del Crédito Público. Informe Final Resumen Ejecutivo.

http://www.cadtm.org/IMG/pdf/Informe_Deuda_Externa.pdf

Accessed 17 September 2019

Cavallo, A., Ghezzi, A. \& Balocco, R. (2019). Entrepreneurial ecosystem research: present debates and future directions. International Entrepreneurship and Management Journal. 15(4), 1291-1321.

Champenois, C., Lefebvre, V. \& Ronteau, S. (2020). Entrepreneurship as practice: systematic literature review of a nascent field. Entrepreneurship \& Regional Development. 32(3-4), 281-312.

Cho Tana, B. D. (2015). Análisis del programa del buen gobierno corporativo sobre la importancia y aplicación del directorio en empresas familiares ecuatorianas del sector agrícola, manufacturero y comercial (PhD thesis, Quito/PUCE/2015).

Development Bank of Latin America (2015). Entrepreneurship and innovation strategy for Ecuador.

caf.com/currently/news/2015/04/entrepreneurship-and-innovation-strategy-forecuador/ Accessed 3 September 2019.

Dheer, R.J. \& Lenartowicz, T. (2018). Multiculturalism and entrepreneurial intentions: Understanding the mediating role of cognitions. Entrepreneurship Theory and Practice. 42(3), 426-466.

Diaz-Moriana, V., Clinton, E., Kammerlander, N., Lumpkin, G.T. \& Craig, J.B. (2020). Innovation motives in family firms: A transgenerational view. Entrepreneurship Theory and Practice. 44(2), 256-287.

Drinkwater, S., Lashley, J. \& Robinson C. (2018). Barriers to enterprise development in the Caribbean. Entrepreneurship \& Regional Development. 30(9-10), 942-963.

Edwards, C.J., Bendickson, J.S., Baker, B.L. \& Solomon, S.J. (2020). Entrepreneurship within the history of marketing. Journal of Business Research. 108, 259-267. 
Espinoza, C., Mardones, C., Saez, K. \& Catalan, P. (2019). Entrepreneurship and regional dynamics: the case of Chile. Entrepreneurship \& Regional Development. 31(910), $755-767$.

Faleye, O., Kung, W., Parwada, J.T. \& Tian, G.Y. (2020). Are entrepreneurs special? Evidence from board appointments. Journal of Business Venturing. 35(3), 106003.

Farias, C., Fernandez, P., Hjorth, D. \& Holt, R. (2019). Organizational entrepreneurship, politics and the political. Entrepreneurship \& Regional Development. 31(7-8), 555-566.

Ferrer, A. (2010). Millennials, la generación del siglo XXI. Nueva Revista de Política, Cultura y Arte, 130.

Fischer, B.B., Queiroz, S. \& Vonortas, N.S. (2018). On the location of knowledgeintensive entrepreneurship in developing countries: lessons from Sao Paulo, Brazil. Entrepreneurship \& Regional Development. 30(5-6), 612-638.

Fritsch, M., Sorgner, A. \& Wyrwich, M. (2019). Self-employment and well-being across institutional contexts. Journal of Business Venturing. 34(6), 105946.

GEM (2018). Global Entrepreneurship Monitor. Ecuador. Espai. Guayaquil.

Gish, J.J., Wagner, D.T., Gregoire, D.A. \& Barnes, C.M. (2019). Sleep and entrepreneurs' abilities to image and form initial beliefs about new venture ideas. Journal of Business Venturing. 34(6), 105943.

Global Competitiveness Report (2019). World Economic Forum. http://www3.weforum.org/docs/WEF_TheGlobalCompetitivenessReport2019.pd f Accessed 24 October 2019.

Gluzmann, P., Jaume, D., \& Gasparini, L. (2012). Decisiones laborales en América Latina: el caso de los emprendedores. CAF Documento de trabajo, 2012/06, Caracas. http://scioteca.caf.com/handle/123456789/235 Accessed 21 May 2019.

Gu, W, Qian, X. \& Lu, J. (2018). Venture capital and entrepreneurship: a conceptual model and research suggestions. International Entrepreneurship and Management Journal. 14(3), 35-50.

Guimon, J. \& Paraskevopoulou, E. (2017). Factors shaping the international knowledge connectivity of industrial clusters: a comparative study of two Latin American cases. Entrepreneurship \& Regional Development. 29(9-10), 817-846.

Gumbau, M. (2017). Entrepreneurship, innovation and regional performance: application for the Spanish regions. Entrepreneurship \& Regional Development. 29(3-4), 271-291.

Gupta, P., Chauhan, S., Paul, J. \& Jaiswal, M.P. (2020). Social entrepreneurship research: A review and future research agenda. Journal of Business Research. 113, 209229.

Hearn, B. \& Filatotchev, I. (2019). Founder retention as CEO at IPO in emerging economies: The role of private equity owners and national institutions. Journal of Business Venturing. 34(3), 418-438. 
ICEX (2019): Informe Económico y Comercial. Ecuador. ICEX. Oficina Económica y Comercial de España en Quito. https://www.icex.es/icex/es/navegacionprincipal/todos-nuestros-servicios/informacion-de-mercados/paises/navegacionprincipal/el-mercado/estudios-informes/DOC2015497531.html?idPais=EC Accessed 16 September 2019.

Iliescu, C. (2014). Globalizing knowledge or acknowledging globalization? Sociocultural implications of academic interaction, in Lambert, J. \& Iliescu, C. Universe-cities as problematic global villages: continuities and shifts in our academic worlds. 33-77. Copiart PGET/UFSC, Florianopolis, Brazil.

INEC (2019). Instituto Nacional de Estadísticas y Cuentas de Ecuador. https://www.ecuadorencifras.gob.ec/institucional/home/ Accessed 18 October 2019.

INEC (2020). Instituto Nacional de Estadísticas y Cuentas de Ecuador. http://www.ecuadorencifras.gob.ec/ Accessed 12 July 2020.

Keil, T., Maula, M. \& Syrigos, E. (2017). CEO entrepreneurial orientation, entrenchment, and firm value creation. Entrepreneurship Theory and Practice. 41(4), 475-504.

Larrea, C. (2007). Ecuador: Un dilema de trascendencia hacia el futuro. Diario La Insignia. May, 12.

Lasso, S., Mainardes, E. \& Motoki, F. (2019). Why do entrepreneurs open tech startups? A comparative study between Brazilian and foreign enterprises. International Entrepreneurship and Management Journal. 15(1), 233-255.

Lecuna, A., Cohen, B., \& Chavez, R. (2017). Characteristics of high-growth entrepreneurs in Latin America. International Entrepreneurship and Management Journal 13(1), 141-159.

Lederman, D., Messina, J., Pienknagura, S., \& Rigolini, J. (2014). Latin American entrepreneurs. Many firms but little innovation. World Bank Publications. Washington D.C.

López, E.G., Carreño, O.F., Alarcón, L.F. \& Reinoso, M.V. (2017). El emprendimiento en el sistema universitario. Revista Didasc@lia: Didáctica y Educación. 8(1), 163- 178 .

Maldonado, B., Lara, G. \& Maya, A. (2018). Actividad emprendedora y competitividad en el Ecuador. Revista Global de Negocios. 6(1), 29-44.

Marshall, D.R. \& Gigliotti, R. (2020). Bound for entrepreneurship? A career-theoretical perspective on entrepreneurial intentions. International Entrepreneurship and Management Journal. 16(1), 287-303.

Mazzei, M., Ketchen, D.J. \& Shook, C.L. (2017). Understanding strategic entrepreneurship: a "theoretical toolbox" approach. International Entrepreneurship and Management Journal. 13(2), 631-663.

Mazzei, M. (2018). Strategic entrepreneurship: Content, process, context, and outcomes. International Entrepreneurship and Management Journal. 14(3), 657-670. 
Maya, A., Lara, G. \& Maldonado, B. (2015). Influencia de las políticas y programas de fomento a la actividad emprendedora en el Ecuador. IX Workshop de la Red EmprendeSUR, 871-888. Universidad FASTA, Mar del Plata.

Meoli, A., Fini, R., Sobrero, M. \& Wiklund, J. (2020). How entrepreneurial intentions influence entrepreneurial career choices: The moderating influence of social context. Journal of Business Venturing. 35(3), 105982.

Merizalde, D.C, (2017). Financiamiento de los emprendimientos ecuatorianos, in Jaime, E.E. El emprendimiento en Ecuador. Visión y perspectivas. 69-91. ECOTEC University.

Olmedo, M. C. (2016). Estudio del caso: Análisis de los niveles de renta que afectan el incremento neto de la riqueza económica del Ecuador período 2014-2016 Master's thesis, University of Guayaquil, School of Economics.

Omri, A. (2020). Formal versus informal entrepreneurship in emerging economies: The roles of governance and the financial sector. Journal of Business Research. 108, (277-290).

Ordeñana, X. \& Villa, R. (2014). Mobility and entrepreneurship in Ecuador: A dynamic pseudo-panel approach. Latin American Journal of Economics. 51(2), 307-341.

Ponguillo, K.A. \& Mayorga, R.X. (2016). Desarrollo del emprendimiento en el Ecuador. Revista Caribeña de Ciencias Sociales,

http://www.eumed.net/rev/caribe/2016/02/crecimiento.htm. Accessed 18 October 2019.

Proaño, L.F.H. (2015). Fundamentos teórico-metodológicos para la formación en emprendimiento y el desarrollo de la capacidad de innovación en profesionales. Caso de estudio: Facultad de Especialidades Empresariales, UCSG. Alternativas, 16(2), 20-26.

Puente, R., Gonzalez, C.G. \& Cervilla, M.A. (2019). Necessity entrepreneurship in Latin America: it's not that simple. Entrepreneurship \& Regional Development 31(910), 953-983.

Rovayo, G. (2010). Los Tres Desafíos del Emprendedor Ecuatoriano: Capital, Capacitación, Confianza. Revista Emprende, 1-3.

Serrano, L.A. \& Vera, A. (2016). Ecuador: Deuda Externa, Ingresos Tributarios y Crecimiento Económico, 2000-2014. Case study. Observatorio de la Economía Latinoamericana, (222). https://ideas.repec.org/a/erv/observ/y2016i22221.html. Accessed 17 May 2018.

Solines, V., y Antonieta, V. (2016). Evaluación del levantamiento de fondos que contribuyan al desarrollo del programa de emprendimiento The click ( $\mathrm{PhD}$ thesis, Universidad Casa Grande. Facultad Mónica Herrera).

Spigel, B. \& Harrison, R. (2017). Towards a process theory of entrepreneurial ecosystems. Strategic Entrepreneurship Journal. 12(1), 151-168.

Toms, S., Wilson, N. \& Wright, M. (2019). Innovation, intermediation, and the nature of entrepreneurship: A historical perspective. Strategic Entrepreneurship Journal. $14(1), 105-121$. 
United Nations, ECLAC (2016). Economic Survey of Latin America and the Caribbean 2016: The 2030 Agenda for Sustainable Development and the challenges of financing for development. United Nations, Santiago de Chile.

Universum. (2014). You got us wrong. Millennials prove they are diverse in their career aspirations and desire for work-life balance. Universum.

http://www.peoplematters.com/Archivos/Descargas/Informes/Part\%204\%20\%20You\%20got\%20us\%20wrong.pdf Accessed 17 April 2019.

Valencia, F.A. \& Gualdrón, S.T. (2016). Entorno y motivaciones para emprender. Revista Escuela de Administración de Negocios, (81), 12-28.

Varlander, S.W., Solvell, I. \& Klyver, K. (2020). Entrepreneurship as a vocational choice in contested entrepreneurship communities: The role of entrepreneurs' justification strategies. Journal of Business Venturing. 35(3), 106006.

Villarroel, C., Maragno, P., Fernández, M., \& Itriago, M. (2005). Determinación y validación del perfil de competencias de los ingenieros venezolanos y relación con contenidos curriculares básicos e indispensables. Universidad Central de Venezuela. Caracas, 151.

Watson, A., Dada, O., Wright, O. \& Perrigot, R. (2019). Entrepreneurial orientation rhetoric in franchise organizations: The impact of national culture. Entrepreneurship Theory and Practice. 43(4), 751-772.

Westgren, R. \& Wuebker, R. (2019). An economic model of strategic entrepreneurship. Strategic Entrepreneurship Journal. 13(4), 507-528.

Wiklund, J., Nikolaev, B., Shir, N., Foo, M. \& Bradley, S. (2019). Entrepreneurship and well-being: Past, present, and future. Journal of Business Venturing. 34(4), 579588.

World Bank (2019a). Ranking and Ease of doing business score. doingbusiness.org/en/rankings Accessed 17 October 2019.

World Bank (2019b). Time required to start a business. https://data.worldbank.org/indicator/IC.REG.DURS?view=chart. Accessed 28 September 2019.

Zamora, C.S. (2017). La importancia del emprendimiento en la economía: el caso de Ecuador. Revista Espacios, 39(7), 15-26. 
Table 1: Summarized technical specifications of the research study

\begin{tabular}{l|l}
\hline Unit of Analysis: & Entrepreneurs \\
\hline Population: & $\begin{array}{l}173 \text { enterprises. This population was determined according to: } \\
\text { heterogeneity; geographical representativeness of important } \\
\text { territorial areas in Ecuador; real scope available in terms of time; } \\
\text { and access to possible updated and reliable information. }\end{array}$ \\
\hline Territorial Scope: & Ecuador \\
\hline Time Scope: & $\begin{array}{l}\text { The fieldwork period and its statistical analysis comprised the } \\
\text { first six months of 2018. }\end{array}$ \\
\hline Sample size: & $\begin{array}{l}132 \text { enterprises (Finite populations). Taking into account } \\
\text { representativeness, relevance, and access to entrepreneurs. }\end{array}$ \\
\hline Sample selection procedure: & Simple random sampling \\
\hline Sample error margin: & Below 5\% \\
\hline Confidence Interval: & $95 \%$ \\
\hline Information collecting procedure: & $\begin{array}{l}\text { Primary, by means of interviews and surveys applied on a self- } \\
\text { administered basis, directly provided to the participants or via } \\
\text { electronic mail }\end{array}$ \\
\hline Information processing: & $\begin{array}{l}\text { Microsoft Office, Microsoft Excel, and the statistical program } \\
\text { SPSS version 22 for Windows }\end{array}$ \\
\hline
\end{tabular}

Source: Elaborated by the authors

Table 2: Geographical distribution (frequency and percentages)

\begin{tabular}{c|ccc}
\hline \multicolumn{1}{c}{} & & Frequency & Percentage \\
\hline \multirow{7}{*}{ Valid } & Guayaquil & 32 & $24.2 \%$ \\
& Quito & 22 & $16.7 \%$ \\
& Cuenca & 28 & $21.2 \%$ \\
& Santo Domingo & 7 & $5.3 \%$ \\
& Portoviejo & 10 & $7.6 \%$ \\
& Manta & 10 & $7.6 \%$ \\
& Durán & 6 & $4.5 \%$ \\
& Machala & 11 & $8.3 \%$ \\
& Others & 6 & $4.5 \%$ \\
& Total & 132 & $100.0 \%$ \\
\hline
\end{tabular}

Source: Elaborated by the authors 
Table 3: Origin of capital (frequency and percentages)

\begin{tabular}{lcrr}
\hline & Frequency & Percentage \\
\hline \multirow{3}{*}{ Origin of Capital } & 5 & $3.8 \%$ \\
& Undefined & 42 & $31.8 \%$ \\
& Fational Private & 85 & $64.4 \%$ \\
& Foreign Private & 132 & $100.0 \%$ \\
\hline
\end{tabular}

Source: Elaborated by the authors

Table 4: Summary of Ecuadorean entrepreneurs' characteristics

\begin{tabular}{|l|l|}
\hline $\begin{array}{l}\text { Most highly valued aspect when it comes to } \\
\text { becoming an entrepreneur }\end{array}$ & Financing (6.36) \\
\hline Most recognized knowledge & $\begin{array}{l}\text { Multidimensional approach of the programs to be } \\
\text { developed (5.97) }\end{array}$ \\
\hline Impediments to become an entrepreneur & Lack of financing (5.74) \\
\hline Knowledge and skills required & Perseverance and interpersonal skills (5.72) \\
\hline Ability to manage emotions & Despair (5.39) \\
\hline
\end{tabular}

Source: Elaborated by the authors 
Table 5: Correlations between unemployment and influential variables

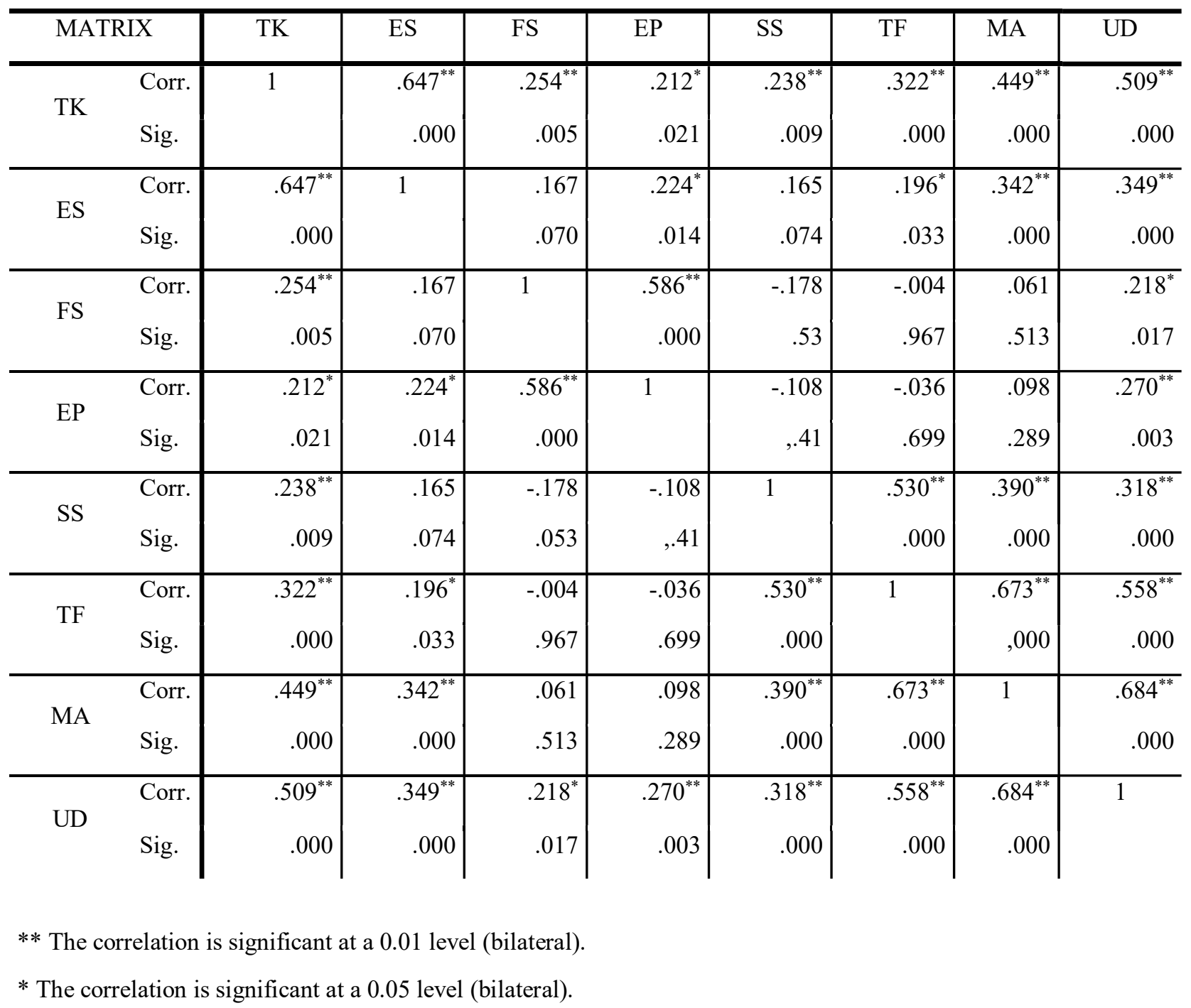

Source: Elaborated by the authors

Table 6: Model summary

\begin{tabular}{|l|r|r|r|r|r|}
\hline Model & R & R square & \multicolumn{1}{|c|}{$\begin{array}{c}\text { Corrected R } \\
\text { square }\end{array}$} & $\begin{array}{c}\text { Estimate typical } \\
\text { error }\end{array}$ & Durbin-Watson \\
\hline 1 & $.755^{\mathrm{a}}$ & .571 & .544 & .784 & 1.805 \\
\hline
\end{tabular}

a. Predictor variables: (Constant), MA, FS, ES, SS, EP, TK, TF

Source: Elaborated by the authors 
Table 7. ANOVA

\begin{tabular}{|l|l|r|r|r|r|}
\hline \multicolumn{2}{|l|}{ Model } & Sum of squares & $\begin{array}{c}\text { Root mean } \\
\text { square }\end{array}$ & F & \multicolumn{1}{c|}{ Sig. } \\
\hline \multirow{3}{*}{1} & Regression & 90.622 & 12.946 & 21.081 & $.000^{\mathrm{a}}$ \\
\cline { 2 - 6 } & Residual & 68.168 & .614 & & \\
\cline { 2 - 6 } & Total & 158.790 & & & \\
\hline
\end{tabular}

a. Dependent variable: UD

Source: Elaborated by the authors

Table 8: Model coefficients

\begin{tabular}{|c|c|c|c|c|c|}
\hline \multirow{2}{*}{ Model } & \multicolumn{2}{|c|}{ Non-standardized coefficients } & \multirow{2}{*}{$\begin{array}{c}\begin{array}{c}\text { Typified } \\
\text { coefficients }\end{array} \\
\text { Beta }\end{array}$} & \multirow[b]{2}{*}{$\mathrm{t}$} & \multirow[b]{2}{*}{ Sig. } \\
\hline & B & Typical Error & & & \\
\hline (Constant) & -.799 & .633 & & -1.263 & 209 \\
\hline TK & .248 & .103 & .214 & 2.413 & .017 \\
\hline ES & -.029 & .088 & -.027 & -.326 & .745 \\
\hline FS & .032 & .054 & .047 & .590 & .556 \\
\hline EP & .142 & .066 & .170 & 2.164 & .033 \\
\hline SS & .033 & .103 & .025 & .325 & .746 \\
\hline TF & .223 & .107 & .192 & 2.078 & .040 \\
\hline MA & .585 & .120 & 439 & 4.868 & .000 \\
\hline
\end{tabular}

Source: Elaborated by the authors 